\title{
ANALISIS BURDEN OF DISEASE HIPERTENSI PADA MASYARAKAT DI KABUPATEN KEDIRI
}

\section{THE ANALYSIS OF HYPERTENSION BURDEN DISEASE IN THE COMMUNITY OF KEDIRI DISTRICT}

\author{
Atika Binti Utari ${ }^{1}$, Thinni Nurul Rochmah ${ }^{1}$ \\ ${ }^{1}$ Departemen Administrasi dan Kebijakan Kesehatan \\ Fakultas Kesehatan Masyarakat Universitas Airlangga, Surabaya, Indonesia \\ Alamat Korespondensi: AtikaBintiUtari \\ E-mail: atikabintarii@gmail.com
}

\begin{abstract}
The incidence of hypertension is the highest non-communicable disease in Kediri in 2016. The prevalence of hypertension in Kediri reaches 27.9. This situation even exceeds the prevalence rate in East Java (26.2). This study aims to calculate the value of economic losses caused by hypertension sufferers in Kediri. This research is a quantitative research with the cross-sectional method. The primary data collection was done by interviewing 100 hypertension sufferers. The results show that the direct medical cost incurred by patients due to hypertension is IDR 563,360 per capita. Meanwhile, the indirect costs to be incurred by patients during suffering hypertension reach IDR 789,272 per capita. Disability-Adjusted Life Years or years lost due to premature death and disability caused by hypertension disease in Kediri regency amount to 189,915 years. Consequently, the Burden of disease value obtained due to hypertension in Kediri District is IDR 330,882,930,485. It can be concluded that the economic burden caused by hypertension is significantly high. The indirect costs incurred by the patients are greater than the direct costs. Therefore, it is recommended to intensify the dissemination and preventive efforts to decrease the incidence of hypertension.
\end{abstract}

Keywords: burden of disease, DALYs, hypertension

\begin{abstract}
ABSTRAK
Insiden hipertensi menempati urutan tertinggi penyakit tidak menular di Kabupaten Kediri Tahun 2016. Prevalensi hipertensi di Kabupaten Kediri sebesar 27,9. Hal ini bahkan melebihi angka prevalensi di Jawa Timur yaitu 26,2. Penelitian ini bertujuan untuk menghitung nilai kerugian ekonomi yang diakibatkan oleh penderita hipertensi pada masyarakat di Kabupaten Kediri. Penelitian ini merupakan penelitian kuantitatif dengan metode cross sectional. Pengumpulan data primer dilakukan dengan cara wawancara kepada 100 penderita hipertensi. Hasil penelitian menunjukkan bahwa biaya langsung yang dikeluarkan oleh penderita akibat hipertensi adalah sebesar Rp 563.360,- per kapita. Biaya tidak langsung yang harus dikeluarkan oleh penderita selama menderita hipertensi adalah sebesar Rp 789.272,- per kapita. Dissability Adjusted Life Years atau tahun yang hilang akibat kematian dini dan kecacatan yang disebabkan penyakit hipertensi di Kabupaten Kediri adalah sebesar 189.915 tahun. Nilai Burden of disease akibat hipertensi pada masyarakat di Kabupaten Kediri adalah sebesar Rp 330.882.930.485,-. Disimpulkan bila beban ekonomi yang diakibatkan hipertensi sangat tinggi. Besar biaya tidak langsung yang dikeluarkan oleh penderita lebih besar dari pada biaya langsung. Terdapat penderita hipertensi yang belum menyadari besarnya kerugian ekonomi akibat penyakit hiperteni yang diderita. Dapat direkomendasikan untuk menggiatkan upaya promotif dan preventif untuk menekan insiden hipertensi.
\end{abstract}

Kata kunci:burden of disease, DALYs, hipertensi

\section{PENDAHULUAN}

Permasalahan kesehatan di Indonesia cukup kompleks, pada sepuluh tahun terakhir ini Indonesia mengalami triple burden disease. Penyakit menular masih sangat tinggi, namun di sisi lain terjadi peningkatan pada penyakit tidak menular dan munculnya penyakit menular baru (new emerging disease). Menurut WHO (2014), angka kematian akibat penyakit tidak menular akan terus mengalami kenaikan di seluruh dunia. Pada tahun 2030, diperkirakan terjadi 52 juta kematian akibat penyakit tidak menular. Salah satu penyakit tidak menular yang menjadi masalah kesehatan masyarakat adalah 
hipertensi. Tidak saja di negara berkembang tetapi juga di negara maju.

Hipertensi biasa disebut dengan silent killer karena gejalanya tidak diketahui pasti. Gejala yang muncul dapat berbeda-beda pada masing-masing individu dan hampir sama dengan penyakit lainnya. Selain itu hipertensi juga merupakan faktor risiko penyebab penyakit mematikan seperti stroke dan jantung koroner. Riskesdas (2013) menunjukkan bahwa secara nasional $25,8 \%$ penduduk Indonesia menderita penyakit hipertensi.

Jumlah kasus baru hipertensi di Kabupaten Kediri mengalami kenaikan dari tahun ke tahun. Pada tahun 2016 insiden hipertensi menduduki urutan pertama penyakit tidak menular di Kabupaten Kediri. Angka prevalensi hipertensi bahkan mencapai 27,9. Angka ini lebih tinggi dari angka prevalensi hipertensi jawa timur yaitu 26,2. Untuk penyakit tidak menular, pada tahun 2016 hipertensi menduduki urutan pertama penyakit tidak menular.

Tingginya angka insiden hipertensi perlu diwaspadai bagi bagi suatu wilayah. Semakin tingginya kejadian penyakit hipertensi ini menimbulkan kerugian sosial ekonomi dan berdampak bukan hanya pada masyarakat namun juga bagi negara karena menurunkan angka produktivitas.

Burden of Disease merupakan beban ekonomi yang ditanggung atas episode sakit dari suatu penyakit yang diderita oleh masyarakat di daerah tertentu atau nilai kerugian yang diderita oleh masyarakat tertentu akibat penyakit yang diderita oleh sebagian masyarakat di daerah tersebut. Menurut WHO (2009) perhitungan beban ekonomi ini akan memberikan gambaran tentang penurunan derajat kesehatan dan pengurangan produksi ekonomi atau peluang konsumsi di rumah tangga atau tingkat masyarakat akibat penyakit tertentu.

Jumlah kasus hipertensi yang tinggi dan tidak ditangani dengan baik dapat mengakibatkan kerugian bukan hanya pada sisi ekonomi saja tetapi juga berdampak pada produktivitas dan komplikasi penyakit lainnya. Meningkatnya jumlah kasus hipertensi dapat berdampak pada peningkatan beban ekonomi, penurunan produktivitas dan timbulnya komplikasi.

Penderita hipertensi perlu upaya untuk mempertahankan kesehatannya. Selain pemeriksaan rutin, menjaga pola makan, juga kebutuhan untuk menurunkan tekanan darah. Upaya tersebut memerlukan biaya yang harus ditanggung oleh pasien. Biaya yang dikeluarkan penderita hipertensi akibat sakitnya bukan hanya untuk pengobatan saja namun masih banyak biaya yang dikeluarkan akibat penyakit hipertensi. Adapun komponen biaya yang dikeluarkan penderita hipertensi untuk mempertahankan status kesehatan mereka antara lain: biaya pengobatan dan perawatan, biaya productivity loss, biaya transportasi dan biaya pendamping.

Pada umumnya penderita hipertensi akan merasakan gejala klinis seperti pusing, lemah dan mata berkunangkunang. Kondisi tubuh yang kurang optimal akan menghambat penderita untuk melakukan aktivitas sehari-hari seperti kegiatan rumah tangga, bekerja dan aktivitas lainnya. Absensi kerja dapat terjadi pada penderita hipertensi karena penderita hipertensi sering disarankan untuk beristirahat. Selain itu, ketika penderita hipertensi ingin melakukan check up atau pengobatan lainnya maka terpaksa penderita hipertensi harus meninggalkan pekerjaan atau aktivitas rutinnya. Tekanan darah yang tinggi merupakan faktor risiko utama untuk terjadinya penyakit jantung, stroke, gangguan penglihatan dan ginjal (Nuraini, 2015). Kematian pada pasien hipertensi lebih cepat terjadi pada penyakit yang tidak terkontrol dan menimbulkan komplikasi pada berbagai organ vital.

Untuk itu penelitian ini bertujuan secara umum memperoleh nilai burden of disease penyakit hipertensi yang dialami masyarakat di Kabupaten Kediri. 


\section{METODE PENELITIAN}

Penelitian ini merupakan penelitian kuantitatif dengan rancang bangun cross sectional. Populasi dalam penelitian ini adalah seluruh penderita hipertensi di Kabupaten Kediri pada tahun 2017 yaitu sebesar 435.628 orang. Penghitungan sampel menggunakan rumus Slovin sehingga didapatkan besar sampel sebanyak 100 orang responden penderita hipertensi.

Teknik pengambilan sampel pada penelitian ini adalah menggunakan cluster random sampling. Tahap pertama pengambilan sampel dimulai dengan menentukan cluster yaitu menggunakan kelompok wilayah kerja Puskesmas. Terdapat pertimbangan dalam memilih Puskesmas untuk dijadikan sampel agar dapat mewakili populasi, yaitu dengan memilih Puskesmas yang termasuk di daerah pedesaan dan perkotaan. Terpilih 2 Puskesmas yang memenuhi kriteria tersebut, yaitu Puskesmas Kandangan (mewakili daerah pedesaan) dan Puskesmas Pare (mewakili daerah perkotaan).

Pengambilan data pada penelitian ini dilakukan dengan cara door to door pada penderita hipertensi di wilayah kerja Puskesmas Pare dan Puskesmas Kandangan secara acak. Instrumen pengambilan data pada penelitian ini adalah menggunakan kuessioner.

Waktu penelitian dilakukan pada bulan Mei sampai Juli 2017. Variabel untuk menghitung nilai Burden of Disease dalam penelitian ini terdiri dari biaya langsung, biaya tidak langsung, Dissability Adjusted Life Years, jumlah penduduk dan prevalensi hipertensi. Alat bantu analisis data dalam penelitian ini menggunakan program Ms.Excel. Penelitian ini telah memperoleh keterangan lolos kaji etik dari Komisi Etik FKM No : 129-KEPK

\section{HASIL}

\section{Biaya Langsung}

Biaya langsung adalah biaya yang berhubungan langsung dengan pengobatan hipertensi. Biaya ini merupakan biaya yang dikeluarkan oleh penderita hipertensi untuk memeriksakan kesehatannya. Biaya langsung akan terbagi menjadi dua kategori yaitu biaya rutin dan biaya insidental. Biaya Rutin merupakan biaya langsung yang secara rutin dikeluarkan oleh penderita selama sakit. Biaya rutin ini dihitung dalam satu tahun (Istiqomah, 2016).

Pada penelitian ini biaya yang merupakan biaya langsung rutin adalah biaya rawat jalan dan biaya pengobatan lainnya. Biaya rawat jalan didapatkan dari rata-rata pengeluaran untuk pengobatan rawat jalan oleh penderita selama satu tahun. Biaya pengobatan lainnya menunjukkan rata-rata biaya pengobatan lain yang dikeluarkan oleh penderita selama satu tahun. Pengobatan lainnya yang dimaksud adalah pengobatan yang tidak dilakukan di pelayanan kesehatan, misalnya membeli obat sendiri di apotek, membeli obat tradisional maupun pengobatan alternatif lainnya yang secara rutin dilakukan penderita.

Tabel 1. Biaya Langsung Pada Penderita Hipertensi di Kabupaten Kediri

\begin{tabular}{lr}
\hline Keterangan & Biaya (Rupiah) \\
\hline BIAYA INSIDENTIL & \\
Rata-rata Biaya Rawat Inap & 216.150 \\
BIAYA RUTIN & \\
Rata-rata Biaya Rawat Jalan & 288.790 \\
Rata-rata Biaya Pengobatan Lain & 58.420 \\
Rata-rata Biaya Langsung Rutin & 347.210 \\
Rata-rata Biaya Langsung & 563.360 \\
\hline
\end{tabular}


Biaya insidental merupakan biaya langsung yang dikeluarkan sewaktu-waktu selama penderita mengalami sakit. Biaya yang termasuk biaya langsung insidental pada penelitian ini adalah biaya rawat inap. Biaya rawat inap termasuk dalam biaya insidental karena penderita tidak selalu membutuhkan pengobatan rawat inap setiap tahunnya. Biaya rawat inap ini merupakan rata-rata pengeluaran untuk pengobatan rawat inap selama menderita hipertensi.

Berdasarkan Tabel 1 dapat disimpulkan bahwa biaya langsung yang dikeluarkan penderita hipertensi adalah sebesar Rp 563.360,-. Komponen terbesar dalam biaya langsung adalah terdapat pada biaya langsung rutin yaitu biaya untuk pengobatan rawat jalan.

\section{Biaya Tidak Langsung}

Biaya tidak langsung merupakan biaya yang tidak berhubungan langsung dengan pengobatan hipertensi yang ditanggung penderita selama sakit. Biaya tidak langsung dibagi menjadi dua kategori yaitu biaya tidak langsung rutin dan biaya tidak langsung insidental. Biaya tidak langsung rutin merupakan biaya tidak langsung yang dikeluarkan penderita secara rutin selama penderita mengalami sakit hipertensi. Sedangkan biaya tidak langsung insidental merupakan biaya tidak langsung yang sewaktu-waktu dikeluarkan penderita selama sakit (Istiqomah, 2016).

Pada penelitian ini biaya tidak langsung rutin terdiri dari biaya transportasi rawat jalan, productivity loss penderita rawat jalan, dan productivity loss pendamping rawat jalan. Sedangkan biaya tidak langsung insidental terdiri dari biaya transportasi rawat inap, biaya alat bantu, productivity loss penderita rawat inap, dan productivity loss pendamping rawat inap.

Biaya transportasi merupakan biaya transportasi yang dikeluarkan saat mengunjungi pelayanan kesehatan untuk berobat. Biaya transportasi didapatkan dengan mengalikan jumlah kunjungan dengan rata-rata biaya sekali jalan ke pelayanan kesehatan yang dituju. Biaya alat bantu merupakan biaya yang dikeluarkan untuk membeli alat bantu selama menderita hipertensi. Biaya productivity loss merupakan biaya produktivitas yang hilang akibat penderita meninggalkan pekerjaan atau aktivitas normalnya untuk menjalani pengobatan (Istiqomah, 2016). Biaya productivity loss didapatkan dengan mengalikan persentase jumlah absen dalam sebulan untuk menjalani pengobatan dengan rata-rata pendapatan setiap bulan.

Berikut ini merupakan hasil penghitungan biaya tidak langsung yang dapat dilihat pada Tabel 2 .

Tabel 2. Biaya Tidak Langsung pada Penderita Hipertensi di Kabupaten Kediri

\begin{tabular}{lr}
\hline Keterangan & Biaya (Rupiah) \\
\hline BIAYA INSIDENTIL & \\
Rata-rata Transportasi Rawat inap & 44.952 \\
Rata-rata Biaya Alat Bantu & 0 \\
Rata-rata Productivity Loss Pada Penderita Rawat Inap & 78.389 \\
Rata-rata Productivity Loss Pada Pendamping Rawat Inap & 76.357 \\
Rata-rata Biaya Tidak Langsung Insidentil & 199.698 \\
BIAYA RUTIN & \\
Rata-rata Transportasi Rawat Jalan & 168.667 \\
Rata-rata Productivity Loss Pada Penderita Rawat Jalan & 182.283 \\
Rata-rata Productivity Loss Pada Pendamping Rawat Jalan & 91.112 \\
Rata-Rata Biaya Tidak Langsung Rutin & 442.062 \\
\hline TOTAL BIAYA & $\mathbf{7 8 9 . 2 7 2}$ \\
\hline
\end{tabular}


Berdasarkan Tabel 2 dapat diketahui bahwa besaran biaya tidak langsung adalah sebesar 789.272,-Komponen terbesar adalah dari biaya rutin yaitu biaya productivity loss pada penderita rawat jalan dan transportasi rawat jalan. Pengeluaran untuk alat bantu pada seluruh responden adalah $\mathrm{Rp} 0,-$. Hal ini menunjukkan bahwa seluruh responden tidak mengeluarkan biaya alat bantu akibat hipertensinya.

\section{Dissability Adjusted Life Years (DALYs)}

Menurut WHO (2009) DALYs merupakan indikator dari $B O D$ dalam populasi. Satu $D A L Y s$ dapat diartikan satu tahun dengan kondisi sehat yang hilang akibat suatu penyakit atau kecacatan. $D A L Y s$ adalah perbedaan antara situasi saat ini dan situasi yang ideal di mana setiap orang hidup sampai usia harapan hidup standar, dan dalam kondisi kesehatan yang sempurna. Penghitungan DALYs bukan hanya berdasarkan akibat kematian dini namun juga kecacatan akibat suatu penyakit. DALYs merupakan jumlah tahun yang hilang akibat kematian dini atau disabilitas karena suatu penyakit.

Nilai DALYS didapat dari penjumlahan nilai dari dua dimensi yaitu nilai tahun yang hilang akibat kematian dini (Years Life Lost) dan nilai tahun yang hilang akibat kecacatan mental maupun fisik yang diakibatkan oleh penyakit atau cedera yang disesuaikan dengan tingkat keparahan (frekuensi dan intensitas) (Years Lifed with Dissability).

\section{Years Life Lost (YLL)}

Nilai $Y L L$ menunjukkan tahun yang hilang akibat kematian dini yang disebabkan suatu penyakit. Nilai YLL didapatkan dari pengalian usia harapan hidup di suatu wilayah dengan jumlah kematian akibat penyakit tersebut di suatu wilayah (WHO, 2009). Usia harapan penduduk di Kabupaten Kediri didapatkan dari proyeksi hasil sensus penduduk tahun 2010 sehingga didapatkan hasil usia harapan hidup penduduk Kabupaten Kediri tahun 2017 adalah 72. Berdasarkan data yang diperoleh dari Seksi Pencegahan dan Pengendalian Penyakit Tidak Menular Dinas Kabupaten Kabupaten Kediri, jumlah kematian akibat hipertensi adalah sebesar 402 jiwa pada tahun 2016.Berikut ini adalah penghitungan nilai YLL:

$$
\begin{aligned}
Y L L & =N \times L \\
Y L L & =402 \times 72 \\
& =28.944 \text { tahun }
\end{aligned}
$$

Keterangan

$Y L L=$ Years Life Lost

$N=$ Jumlah Kematian Akibat Hipertensi

$L \quad=$ Usia Harapan Hidup

Berdasarkan penghitungan di atas didapatkan nilai YLL adalah sebesar 28.944 tahun. Artinya terdapat 28.944 tahun yang hilang akibat kematian dini yang disebabkan oleh hipertensi di Kabupaten Kediri.

\section{Years Lifed with Dissability (YLD)}

Menurut WHO (2009) YLD merupakan nilai dari umur yang hilang akibat seseorang mengalami kecacatan baik mental maupun fisik yang diakibatkan dari suatu penyakit. Nilai YLD pada populasi didapatkan dengan mengalikan jumlah insiden penyakit, tingkat keparahan (weight of dissability) dan rata-rata durasi sakit sebelum meninggal.

Berdasarkan data yang diperoleh dari Seksi Pengamatan Penyakit dan Imunisasi Dinas Kabupaten Kediri, jumlah kasus baru hipertensi adalah 44.184. Weight of dissability pada penelitian ini merujuk pada studi burden of disease yang dilakukan oleh Benziger CP dkk (2016) tentang penyakit tidak menular yang bisa dicegah. Pada studi tersebut tingkat keparahan pada penyakit hipertensi termasuk dalam kategori tingkat 2 . Sehingga nilai weight of dissability adalah sebesar 0,220. Sedangkan nilai dari durasi 
sakit didapatkan dari usia harapan hidup dikurangi rata-rata umur mulai sakit pada responden penelitian ini. Usia harapan hidup diperoleh dari BPS bahwa usia harapan hidup penduduk Kabupaten Kediri tahun 2017 yaitu 72 tahun. Rata-rata umur mulai sakit pada responden adalah 55 tahun. Sehingga rata-rata durasi sakit pada responden dalam penelitian ini adalah 17 tahun. Berikut ini adalah penghitungan nilai $D A L Y s$ :

$$
\begin{aligned}
Y L D & =I \times D W \times L \\
Y L D & =44.184 \times 0,220 \times 17 \\
& =160.971 \text { tahun }
\end{aligned}
$$

Keterangan :

$$
\begin{aligned}
\text { YLD } & =\text { Years Lifed with Dissability } \\
I & =\text { Jumlah Kasus Baru Hipertensi } \\
D W & =\text { Dissability Weight (Tingkat } \\
& \text { Keparahan) } \\
L & =\begin{array}{ll}
\text { Durasi sakit sampai sebelum } \\
\text { meninggal }
\end{array}
\end{aligned}
$$

Didapatkan hasil nilai $Y L D$ adalah sebesar 160.971 tahun. Artinya terdapat 160.971 tahun yang dijalani oleh penderita hipertensi di Kabupaten Kediri dengan kondisi sakit.

Setelah mengetahui nilai $Y L L$ dan $Y L D$, maka dapat diperoleh nilai $D A L Y s$ dengan menjumlahkan nilai $Y L L$ dan $Y L D$.
Nilai DALYs adalah sebesar 189.915 tahun. Artinya terdapat 189.915 tahun yang hilang akibat penyakit hipertensi di Kabupaten Kediri.

\section{Jumlah Penduduk}

Berdasarkan data yang diperoleh dari Badan Pusat Statistik (2017) diketahui bahwa jumlah pendudukP Kabupaten Kediri pada tahun 2017 adalah sebesar 1.561.392 jiwa. Berdasarkan data yang didapat dari Seksi Pencegahan dan Pendendalian Penyakit Tidak Menular Dinas Kesehatan Provinsi Jawa Timur diketahui bahwa persentase prevalensi hipertensi di Kabupaten Kediri adalah sebesar 0,279 atau 27,9 \%. Diperkirakan 435.628 penduduk menderita hipertensi di Kabupaten Kediri. Dari jumlah prevalensi ini tidak ditemukan penderita sembuh melainkan terdiri dari penderita yang terus sakit dan penderita yang meninggal. Berdasarkan data yang didapat dari seksi Pencegahan dan Pendendalian Penyakit Tidak Menular Dinas Kesehatan Kabupaten Kediri diketahui jumlah kematian akibat hipertensi adalah sebesar 402 orang. Jumlah penderita terus sakit adalah 435.226 orang. Maka dapat dilakukan proporsi untuk menentukan prevalensi penderita hipertensi terus sakit dan meninggal seperti pada Tabel 3.

Tabel 3. Prevalensi Penderita Hipertensi di Kabupaten Kediri

\begin{tabular}{lccc}
\hline \multicolumn{1}{c}{ Keterangan } & Jumlah (jiwa) & Persentase (\%) & Angka Prevalensi \\
\hline Penderita Terus Sakit & 435.226 & 99,908 & 0,27874 \\
Penderita Meninggal & 402 & 0,092 & 0,00026 \\
Total & 435.628 & 100 & 0,27900 \\
\hline
\end{tabular}

Berdasarkan penghitungan pada Tabel 3 maka dapat disimpulkan bahwa dari seluruh penderita hipertensi di Kabupaten Kediri, prevalensi penderita hipertensi didominasi oleh penderita yang terus sakit yaitu sebesar 0,27874. Prevalensi penderita yang terus meninggal prevalensinya sangat kecil dibanding penderita terus sakit. Angkanya mendekati 0 yaitu sebesar 0,0026 .

\section{Burden Of Disease}

Berdasarkan identifikasi biaya yang telah dilakukan maka dapat dihitung nilai Burden Of Disease dari penyakit hipertensi di Kabupaten Kediri. Pada penelitian ini tidak ditemukan responden yang sembuh atau meninggal. Sehingga penghitungan Burden of Disease akan menggunakan rumus $B O D$ untuk penderita terus sakit sebagai berikut: 


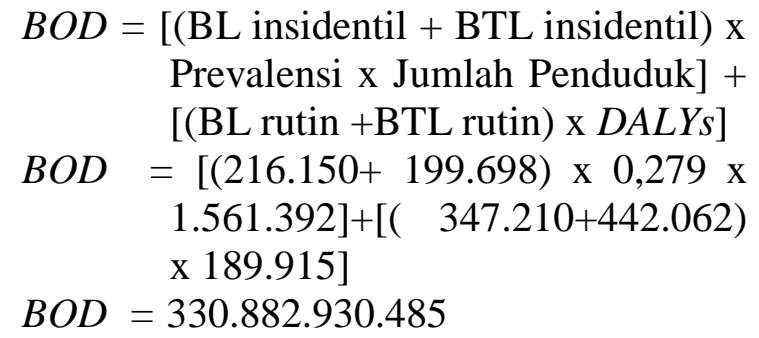

Keterangan :

\begin{tabular}{|c|c|}
\hline BOD & $=$ Burden of Disease \\
\hline BL insidental & $\begin{aligned} &= \text { Total biaya langsung } \\
& \text { insidental r yang } \\
& \text { ditanggung penderita } \\
& \text { hipertensi (rupiah) }\end{aligned}$ \\
\hline BTL insidental & 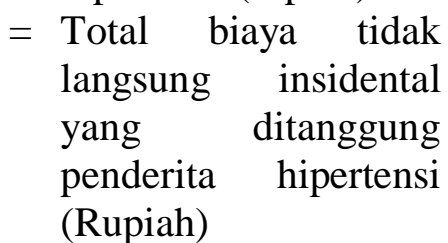 \\
\hline BL rutin & $\begin{aligned} &= \text { Total biaya langsung } \\
& \text { rutin yang ditanggung } \\
& \text { penderita hipertensi } \\
& \text { (Rupiah) }\end{aligned}$ \\
\hline BTL rutin & $\begin{aligned} &= \text { Total biaya tidak } \\
& \text { langsung rutin yang } \\
& \text { ditanggung penderita } \\
& \text { hipertensi (Rupiah) }\end{aligned}$ \\
\hline$D A L Y s$ & $\begin{aligned}= & \text { Dissability Adjusted } \\
& \text { Life Years (Tahun) }\end{aligned}$ \\
\hline Prevalensi & $\begin{aligned}= & \text { Persentase Penderita } \\
& \text { Hipertensi dari jumlah } \\
& \text { penduduk }\end{aligned}$ \\
\hline
\end{tabular}

Jumlah Penduduk $=$ Jumlah $\quad$ Penduduk (jiwa)

Berdasarkan hasil penghitungan di atas dapat disimpulkan bahwa nilai Burden of Disease pada masyarakat akibat penderita hipertensi di Kabupaten Kediri adalah sebesar Rp 330.882.930.485,--

\section{PEMBAHASAN}

Menurut WHO (2004) hampir $45 \%$ beban penyakit yang terjadi pada negara dengan pendapatan rendah dan menengah adalah disebabkan oleh penyakit yang tidak menular. Hipertensi merupakan salah satu penyakit tidak menular yang merupakan faktor risiko utama penyebab kecacatan global, kematian dan dampak yang tidak proporsional di negara berpenghasilan rendah dan menegah, dimana dua per tiga orang menderita hipertensi. Pada tahun 2010 diperkirakan terjadi 9,4 juta kematian dan 162 tahun yang hilang akibat hipertensi di seluruh dunia. Prevalensi hipertensi terus meningkat di seluruh dunia dan diperkirakan mempengaruhi lebih dari 500 juta orang pada tahun 2025. Berdasarkan profil kesehatan Kabupaten Kediri, Hipertensi merupakan penyakit menular dengan jumlah kasus tertinggi selama tahun 2016.

Di Kabupaten Kediri, prevalensi hipertensi mencapai 27,9. Angka prevalensi hipertensi di Jawa Timur adalah 26,2. Disimpulkan angka prevalensi hipertensi di Kabupaten Kediri lebih tinggi dari angka prevalensi hipertensi di Jawa Timur. Angka prevalensi yang tinggi akan meningkatkan beban biaya yang ditanggung oleh masyarakat akibat penyakit yang diderita. Semakin tinggi angka prevalensi suatu penyakit maka semakin tinggi pula $B O D$ yang ditanggung oleh masyarakat akibat penyakit tersebut.

Menurut Bonita R dkk (2006) faktor yang meningkatkan prevalensi suatu penyakit antara lain durasi sakit yang lebih lama. Semakin lama durasi suatu penyakit maka prevalensinya akan cenderung lebih besar. Selain itu pemanjangan usia pasien tanpa pengobatan juga dapat mempengaruhi prevalensi suatu penyakit. Pasien yang tidak mendapat pengobatan akan memperpanjang durasi sakit. Durasi sakit yang semakin lama akan membuat prevalensi akan tetap besar. Semakin banyak pasien yang tidak diobati dapat mempengaruhi tingkat prevalensi. Prevalensi suatu penyakit juga dapat dipengaruhi oleh peningkatan insidensi. Semakin besar peningkatan jumlah kasus baru maka akan meningkatkan prevalensi suatu penyakit. Pada kasus hipertensi, sangat kecil kemungkinan bagi penderita 
untuk sembuh, sehingga prevalensi akan terus meningkat seiring bertambahnya kasus baru.

Bonita R dkk (2006) juga menyatakan bahwa kasus migrasi ke dalam populasi juga dapat meningkatkan prevalensi penyakit. Terjadinya migrasi orang yang terkena suatu penyakit pada suatu populasi dapat menambah jumlah penderita suatu penyakit sehingga dapat meningkatkan prevalensinya pada populasi tersebut. Tingginya prevalensi suatu penyakit juga dapat disebabkan oleh migrasi keluar dari orang-orang sehat. Jika orang-orang yang sehat di daerah tersebut semakin sedikit, maka rasio jumlah orang yang sakit akan semakin besar sehingga tingkat prevalensinya semakin besar.

Bonita R dkk (2006) juga menyatakan bahwa faktor yang mempengaruhi prevalensi selanjutnya adalah migrasi ke dalam dari orang-orang yang rentan. Bertambahnya orang-orang yang rentan akan meningkatkan risiko terjadinya penularan ataupun insiden penyakit di wilayah tersebut. sehingga tingkat prevalensinya akan meningkat. Prevalensi suatu penyakit juga dapat disebabkan karena adanya peningkatan sarana diagnostik. Tingkat prevalensi yang kecil bisa disebabkan masih banyak orang sakit yang belum terdiagnosis. Ketika terjadi peningkatan sarana diagnostik, tingkat prevalensinya akan meningkat.

Apabila hipertensi menyerang pada penderita dengan usia 40-60 tahun akan terganggu aktifitas kerjanya akibat penyakit hipertensi yang diderita. Selain itu, waktu bekerja akan berkurang ketika ia harus menjalani rawat jalan maupun rawat inap akibat penyakit hipertensi yang dideritanya. Jika hipertensi menyerang pada usia lanjut, biasanya sudah memasuki usia pensiun dan tidak bekerja. Biaya hilangnya produktivitas pada penderita dengan usia yang sudah memasuki usia pensiun menjadi tidak setinggi pada usia produktif. Pada usia ini, penderita telah memasuki usia lanjut di mana terjadi penurunan fungsi organ tubuh. Proses degenerasi dan penyakit yang diderita akan meningkatkan keparahan penyakit yang diderita. Penderita akan memerlukan bantuan orang lain saat mengunjungi pelayanan kesehatan untuk rawat jalan maupun rawat inap.

Menurut Chataut dkk (2011) dalam studi yang dilakukan di Nepal pada tahun 2011 menyebutkan bahwa jenis kelamin dan usia lanjut merupakan faktor independen atau faktor risiko hipertensi yang tidak dapat diubah. Penelitian di Subuhan Nepal menunjukkan bahwa prevalensi hipertensi meningkat dengan seiring bertambahnya usia. Kondisi di Kabupaten Kediri dapat membuktikan bahwa bertambahnya usia yang semakin lanjut juga diiringi prevalensi hipertensi yang meningkat.

Hipertensi yang menyerang pada penderita yang tidak berpenghasilan setiap bulannya, sehingga biaya pengobatan hipertensi sangat bergantung pada pendapatan keluarganya. Apabila pendapatan keluarga kurang maka akan menyebabkan ekonomi keluarga semakin terpuruk. Adanya program JKN akan sangat membantu masyarakat untuk menjamin kebutuhan kesehatan agar tetap dapat memeriksakan kesehatannya agar tidak semakin parah. Pada kelompok penderita usia produktif, penderita berpotensi kehilangan produktivitas akibat sakitnya. Pemeriksaan kesehatan dapat dilakukan di luar jam kerja agar tidak mengurangi produktivitasnya.

Burden of Disease (BOD) merupakan konsep yang dikembangkan oleh Harvard School of Public Health, World Bank dan World Health Organization untuk menjelaskan kerugian kesehatan yang dialami akibat kesakitan, kematian dan kecelakaan. BOD adalah beban ekonomi atas episode sakit dari salah satu jenis penyakit yang diderita oleh masyarakat di daerah tertentu atau nilai kerugian yang diderita oleh masyarakat tertentu, akibat penyakit yang diderita oleh sebagian masyarakat di daerah tersebut. Menurut WHO 
(2009) perhitungan beban ekonomi ini akan memberikan gambaran sejauh mana penyakit tertentu menurunkan derajat kesehatan dan mengurangi produksi ekonomi atau peluang konsumsi di rumah tangga atau tingkat masyarakat.

Studi burden of disease mempunyai tujuan untuk menghitung beban yang ditanggung masyarakat pada suatu wilayah akibat sebagian masyarakat yang menderita penyakit tertentu (WHO, 2009). Penghitungan $B O D$ bukan hanya memerlukan data mengenai biaya yang dikeluarkan untuk berobat, namun juga mempertimbangkan biaya tidak langsung termasuk productivity loss akibat penyakit yang diderita. Selain itu dapat menambahkan nilai dari kerugian atas kualitas hidup setelah menderita suatu penyakit. Untuk menghitung $B O D$, langkah yang dilakukan adalah dengan mengumpulkan data yang diperlukan dalam menghitung nilai $B O D$. Data yang perlu dikumpulkan adalah biaya langsung, biaya tidak langsung, DALYs, prevalensi dan jumlah penduduk di wilayah tersebut.

Biaya langsung dan tidak langsung dikelompokkan dalam biaya insidentil dan biaya rutin. Besar biaya langsung insidental yang dikeluarkan oleh penderita hipertensi diperoleh dari biaya rawat inap selama mengalami sakit hipertensi. Biaya yang dikeluarkan bersifat insidentil atau bisa dikeluarkan kapan saja ketika mereka sakit dan pergi ke pelayanan kesehatan, sehingga biaya langsung yang dikeluarkan tidak terduga.

Penelitian ini menunjukkan bahwa besar biaya langsung rutin yang ditanggung oleh penderita hipertensi dalam satu tahun didapatkan dari biaya rawat jalan dan biaya pengobatan lainnya setiap bulannya. Selain melakukan kunjungan rawat jalan di pelayanan kesehatan, beberapa penderita juga membeli obat sendiri di apotek, membeli jamu dan pengobatan alternatif lainnya. Penelitian ini menunjukkan terdapat biaya untuk pengobatan lain sebesar Rp 58.420,-. Biaya ini merupakan biaya pengobatan penderita selain di pelayanan kesehatan.

Selain mengidentifikasi biaya langsung yang dikeluarkan penderita hipertensi, analisis burden of disease juga perlu mengidentifikasi biaya tidak langsung. Pada penelitian ini yang termasuk dalam kategori biaya tidak langsung adalah biaya transpotasi rawat jalan dan rawat inap, biaya alat bantu, dan biaya productivity loss selama rawat jalan dan rawat inap.

Jika dilihat dari segi biaya transportasi, biaya yang dikeluarkan oleh penderita dipengaruhi oleh frekuensi kunjungan ke pelayanan kesehatan. Semakin tinggi frekensi kunjungan maka semakin tinggi pula besar biaya transportasi yang dikeluarkan. Pada penelitian ini penderita menggunakan alat transpotasi yang bermacam-macam untuk menuju pelayanan kesehatan. Mulai dari transportasi motor, mobil, angkutan umum hingga jalan kaki. Pada penelitian ini ditemukan beberapa penderita yang bertempat tinggal di daerah padat penduduk (wilayah kerja Puskesmas Pare) menuju pelayanan kesehatan dengan mengendarai sepeda atau jalan kaki. Hal ini dikarenakan lokasi pelayanan kesehatan yang mudah dijangkau. Transportasi pada penderita di wilayah pedesaan (wilayah kerja Puskesmas Kandangan) cenderung menggunakan motor untuk menuju pelayanan kesehatan.

Hasil penelitian ini menunjukkan bahwa pengeluaran untuk biaya alat bantu pada penderita hipertensi adalah bernilai Rp 0,-. Hal ini dikarenakan manifestasi klinis hipertensi tidak menyebabkan penderita mengalami keterbatasan dalam menjalankan aktivitas sehingga membutuhkan alat bantu.

Pada penelitian ini ditemukan $22 \%$ responden yang bekerja sebagai ibu rumah tangga. Saat penderita sakit, penderita juga akan kehilangan produktivitas untuk melakukan pekerjaan rumahnya. Seperti mencuci, menyapu dan memasak. Walaupun setiap bulannya tidak memiliki 
pendapatan, penderita yang berprofesi sebagai ibu rumah tangga pendapatannya disesuaikan dengan UMR Kabupaten Kediri yaitu sebesar Rp 1.576.120,--

Komponen yang mempengaruhi nilai productivity loss pada penderita adalah frekuensi kunjungan dan pendapatan per bulan. Pada penelitian ini ditemukan beberapa penderita yang tidak bekerja yaitu sebesar 22\%. Hal ini dikarenakan banyaknya penderita dengan usia lanut sehingga sudah tidak memiliki pekerjaan, sehingga productivity loss menjadi rendah.

Berdasarkan analisis di atas dapat disimpulkan bahwa selama sakit hipertensi terdapat biaya tidak langsung yang tidak sedikit yang harus ditanggung oleh penderita akibat penyakit hipertensi. Besar biaya tidak langsung lebih besar dari pada biaya langsung. Masyarakat belum menyadari bahwa penyakit hipertensi yang dialami dapat menimbulkan kerugian ekonomi yang secara tidak langsung dapat mempengaruhi kondisi ekonomi rumah tangga, regional bahkan suatu negara.

Beban biaya yang ditanggung akibat suatu penyakit dipengaruhi oleh Dissability Adjusted Life Years yang merupakan penjumlahan dari jumlah tahun yang hilang akibat kematian dini akibat suatu penyakit atau $Y L L$ dan jumlah tahun yang dijalani penderita dengan ketidakmampuan akibat penyakit yang diderita atau Years Lifed with Dissability (YLD) (WHO, 2009).

Penghitungan nilai $Y L L$ dilakukan dengan mempertimbangkan jumlah kematian. Semakin tinggi angka kematian, maka semakin besar nilai $D A L Y$ s. Semakin tinggi jumlah kematian yang terjadi maka akan meningkatkan nilai DALYs. Begitu pula semakin muda usia seseorang terserang suatu penyakit, maka semakin tinggi nilai $D A L Y s$. Tingginya nilai $D A L Y s$ akan menyebabkan beban ekonomi akibat penyakit semakin besar (WHO, 2014).

Menurut Hyder et al (2012) usia produktif pada umumnya dikaitkan dengan orang dengan usia 15-64 tahun. Pada usia itu manusia dianggap lebih banyak menghabiskan masa hidupnya untuk beraktivitas dan bekerja. Pada usia di bawah 15 tahun dan usia di atas 64 tahun dianggap sebagai tanggungan dalam kehidupan rumah tangga.

Pada penelitian ini ditemukan 402 kematian akibat hipertensi dalam satu tahun. Jika penderita yang meninggal adalah pada usia produktif maka akan berdampak pada menurunnya jumlah angkatan kerja di wilayah tersebut. Beban akan sangat terasa jika yang meninggal merupakan tulang punggung bagi keluarganya. Hasil penelitian juga menemukan bahwa rata-rata usia mulai sakit hipertensi pada seluruh responden paling tinggi adalah pada usia 55 tahun. Pada usia itu merupakan usia produktif bagi seseorang untuk bekerja. Jika usia harapan hidup adalah 72 tahun maka terdapat 17 tahun yang harus dijalani penderita dengan kondisi sakit hipertensi atau dapat dikatakan bahwa penderita akan kehilangan 17 tahun hidupnya dengan kondisi yang sehat sebelum meninggal. Hal ini akan berpengaruh terhadap bertambahnya absensi kerja, disabilitas dan pensiun dini. Hal ini akan berdampak pada menurunnya produktivitas kerja, meningkatnya angka ketergantungan, dan meningkatnya kebutuhan konsumsi kesehatan. Hal ini akan berpengaruh pada menurunnya pendapatan per kapita di wilayah tersebut dan usia harapan hidup yang dapat berdampak pada angka pertumbuhan ekonomi dan menurunnya angka kesejahteraan masyarakat.

Berdasarkan hasil penelitian dapat diambil kesimpulan bahwa biaya tidak langsung yang dikeluarkan penderita lebih besar daripada biaya langsung. Masyarakat kurang menyadari bahwa selain biaya langsung untuk pengobatan, terdapat kerugian ekonomi yang lebih besar akibat pengeluaran untuk biaya transportasi, biaya alat bantu dan productivity loss. Penting untuk melakukan penyadaran pada masyarakat untuk meningkatkan upaya preventif dan promotif agar tidak terserang penyakit hipertensi. 
Upaya preventif dan promotif perlu dilakukan untuk menekan tingginya angka prevalensi hipertensi. Upaya preventif dan promotif memerlukan dukungan dari Pemerintah mengingat hasil dari upaya preventif dan promotif tidak bisa dirasakan pada jangka pendek. Melainkan dampak dapat dirasakan dalam jangka panjang dengan penurunan insiden hipertensi sehingga menurunkan BOD. Dukungan dapat dilakukan dengan meningkatkan anggaran untuk upaya promotif dan preventif sehingga lebih banyak program yang bisa dilakukan untuk menurunkan prevalensi hipertensi. Selain itu, Upaya preventif dan promotif yang bisa dilakukan adalah dengan memperluas kegiatan Posyandu Lansia dan juga Prolanis (Program Penanggulangan Penyakit kronis) yang ditujukan untuk penanggulangan penyakit kronis dapat menjangkau lebih banyak masa dan kegiatan yang variatif.

Upaya preventif dan promotif perlu ditingkatkan mengingat selain biaya langsung untuk pengobatan, hal yang perlu dipertimbangkan yaitu tingginya biaya tidak langsung akibat biaya transportasi dan hilangnya produktivitas bagi penderita maupun pendamping akibat penyakit yang diderita. Upaya preventif dan promotif memerlukan komitmen dan partisipasi aktif dari pihak SDM Kesehatan maupun dari masyarakat agar upaya yang dilakukan dapat berjalan dengan baik.

\section{SIMPULAN}

Total biaya langsung yang dikeluarkan oleh penderita hipertensiRp 563.360,- yang terdiri dari $\mathrm{Rp} 216.150$,dari biaya langsung insidentil dan Rp347.210,- dari biaya langsung rutin. Biaya tidak langsung yang dikeluarkan oleh penderita hipertensi adalah sebesar Rp 789.272,-. Biaya ini terdiri dari biaya tidak langsung isidentil sebesar Rp 199.698,dan biaya tidak langsung rutin sebesar $\mathrm{Rp}$ 442.062,-.

Hasil penelitian ini didapatkan nilai $Y L L$ adalah sebesar 28.944 tahun.
Sedangkan nilai $Y L D$ adalah sebesar 160.971 tahun. Sehingga didapatkan nilai DALYs adalah sebesar 189.915 tahun. Jumlah penduduk Kabupaten Kediri pada tahun 2017 adalah sebesar 1.561.392 jiwa. Prevalensi hipertensi terus sakit di Kabupaten Kediri adalah sebesar 27,874\%. Sedangkan untuk prevalensi penderita meninggal adalah sebesar 0,026\% penduduk. Berdasarkan hasil penghitungan yang dilakukan, maka didapatkan nilai $B O D$ atau beban biaya yang ditanggung akibat hipertensi di Kabupaten Kediri pada masyarakat adalah sebesar Rp 330.882.930.485,-

\section{DAFTAR PUSTAKA}

Badan Pusat Statistik. 2017. Proyeksi Penduduk Kabupaten Kediri 20112020. Kediri: Badan Pusat Statistik

Bonita, R., Beaglehole, R., Kjellstrom, T. 2006. Basic Epidemiology. 2nd edition. WHO. Switzerland.

Benziger CP, Roth GA, Moran AE. The Global Burden of Disease study and the preventable burden of NCD. Global Heart. 2016 Dec 8; 11(4):393-397. [https://doi: 10.1016/j.gheart.2016.10.024].

Chataut J, Adjikari R.K., Sinha N.P., 2011.Prevalence And Risk Factors for Hypertension in Adult Living in Central Development Regiaon in Nepal. Kathmandu University Medical Journal, [e-journal] 33 (1) pp. 8-13.

Hyder, A. A., Puvanachandra, P., \& Morrow, R. H. (2012). Measuring the Health of Populations: Explaining Composite Indicators. Journal of Public Health Research, 1(3), 222-228. [http://doi.org/10.4081/jphr.2012.e 35]

Istoqomah, AN.2016. Analisis Burden of Disease Akibat Hipertensi Pada Masyarakat dengan Status PBI 
JKN di Kabupaten Pamekasan. Skripsi.Universitas Airlangga.

Kementrian Kesehatan RI, 2013. Riset Kesehatan Dasar. Jakarta: Badan Penelitian dan Pengembangan Kesehatan

Nuraini, B.2015. Risk Factor of Hypertension. Jurnal kedokteran Universitas Lampung, [e journal]: 4 (5) pp. 12

World Health Organization (WHO). 2004. Global Burden of Disease 2004.
Part 4 Burden of Disease: DALYs. page 47.

World Health Organization (WHO). 2009. WHO: Guide to Identifying The Economic Consequences of Disease and Injury. Geneva : WHO Departement of Health System Financing Health System and Services

World Health Organization (WHO).2014. Global Status Report of Non Communicable Disease 2014.WHO. Switzerland 